\title{
Szükséges-e mérni a modális erőt, és ha igen, hogyan?*
}

1. Bevezetés. A dolgozat azzal a problémával foglalkozik, hogy a modalitás szakirodalma általában minősíti a modális kifejezéseket (pl. a talán, valószínüleg, vélhetőleg módosítószókat) a modális erősség szempontjából, de eltérő megoldásokat alkalmaz azzal kapcsolatban, hogyan állapítja meg a modális erő(sség) értékét. Az egyszerüség kedvéért a jelen tanulmány csak az episztemikusinferenciális modalitást kifejező magyar módosítószókkal foglalkozik, a kiemelt lexikális kategórián belül pedig a talán, a valószinüleg és a vélhetőleg kifejezésekre összpontosít. Az episztemikus-inferenciális modalitás körébe olyan összetett nyelvi kifejezések tartoznak, amelyek révén a megnyilatkozó megkonstruálja, hogy a jelenet az ő mentális müködésén, következtetésén (megfigyelés esetén annak kiértékelésén és/vagy erre épülő inferenciáján) keresztül elérhető lehetséges tényállás (tehát nem ténylegesen megfigyelhetô szituáció, nem valós előfordulás a résztvevők számára az adott diskurzusban). A modális erő az episztemikusinferenciális modalitásban úgy értelmezhető, hogy a megnyilatkozó a tényállást (a reprezentált jelenetet, 'state of affairs') annak bekövetkezése vagy fennállása szempontjából valamilyen mértékben valószínüsíti. Minél valószínübbnek tartja, a modális erő annál nagyobb, és fordítva.

A tanulmány a 2. pontban pontosítja az eddigiekben csak felvillantott jelenségeket: az episztemikus-inferenciális modalitást, a jelenet megkonstruálásával kapcsolatban az elérés, az információhoz való hozzáférés értelmezését. A 3. pont a modális erővel foglalkozik. Röviden tárgyalja a logikai-formális és a funkcionális szemantikai megközelítéseket, a szakirodalmat nem részleteiben ismertetve, hanem csak kiemelve a modális erő meghatározásában alkalmazott jellemző eljárásokat. A tárgyalás a három magyar módosítószó (talán, valószínüleg, vélhetőleg) modális erejével is foglalkozó magyar munkákra fókuszál. A fejezetpont kifutása a modális erő meghatározásának jelentősége és szükségessége, de a meghatározásra irányuló kísérletek problematikussága is feltárul. A dolgozat bemutat egy újabb kérdőíves vizsgálatot (a 4. pontban), és az eredményeket felhasználva javaslatot fogalmaz meg a modális erő kezelésére és további kutatására. Végül (az 5. pontban) röviden, a főbb állításokat összefoglalva, a javaslatnak megfelelö választ ad a címben feltett kérdésre. A tanulmány példamondatai a Magyar Nemzeti Szövegtárból (v2.0.5, MNSZ. rövidítéssel jelezve; 1. ORAVECZ-VÁRADI-SASS 2014) és az ELTE BTK Mai Magyar Nyelvi Tanszékén található Beszélt Nyelvi Gyüjteményböl ${ }^{1}$ (BNYGY. jelzéssel) származnak.

* A dolgozat elkészítését az NKFIH 129040 számú pályázata (A magyar nyelv igei konstrukciói. Használatalapú konstrukciós nyelvtani kutatás) és a Tématerületi Kiválósági Program (Közösségépítés: család és nemzet, hagyomány és innováció) támogatta.

${ }^{1}$ A gyüjtemény feldolgozása KESZLER BORBÁLA vezetésével történt. A szerző ez úton is köszöni, hogy hozzáférést kapott a digitalizált szövegekhez.

Magyar Nyelv 116. 2020: 429-441. DOI: 10.18349/MagyarNyelv.2020.4.429 
2. Az episztemikus-inferenciális modalitás. Az episztemikus-inferenciális modalitás körébe tipikusan olyan összetett nyelvi kifejezések tartoznak, amelyek révén a megnyilatkozó kifejezésre juttatja, hogy a jelenet az ő mentális müködésén, megfigyelésén és/vagy következtetésén keresztül elérhető lehetséges tényállás (tehát nem ténylegesen megfigyelhető szituáció).

(1) Ez egy nagyon érdekes dolog, ugyanis amikor itt vagyok Pesten, akkor nagyon, nagyon ritkán nézek tv-t, nem tudom, mi az oka ennek, valószinüleg az, hogy itt egészen más lehetőségek is vannak a tv-n kívül [...] (BNYGY.)

(2) A fotóst meg valószínüleg direkt megkérték hogy mutassa meg az alanyok legkevésbé előnyös arcát. (MNSZ.)

Az (1) esetében a megnyilatkozó egyéni hozzáféréssel ('individual access', vö. JAAKOLA 2018: 123-124) rendelkezik mind a vélekedés alapjához (hiszen saját körülményeiröl és motivációiról van szó), mind annak megalkotásához. Más mentális szubjektum nem vonódik be a valószínüsítés müveletébe. A(2) esetében mások is láthatták ugyan a fotókat, de a valószínűsítés kizárólag a megnyilatkozó mentális működésén keresztül megkonstruálódó lehetséges jelenet. Ezekben a példákban a megnyilatkozó az a személy, aki felelős az információért és a valószínüsítésért. Az autoritás vagy felelősség ('authority', vö. BERGQVIST 2016) a magyarban alapértelmezés szerint a megnyilatkozóhoz kötódik. A résztvevők szempontjából ez a viszony az (1)-(2) példában aszimmetrikus. Az episztemikus értékeléssel kapcsolatos felelősség szempontja más nyelvekben a személyhez való lehorgonyzás révén is érvényesülhet: a megnyilatkozó a személyhez kötéssel megjelöli, hogy kinek az illetékességi körébe tartozik az adott jelenet fennállásának vagy lehetséges bekövetkezésének a megítélése (EVANS - BERGQVIST - SAN ROQUE 2018). ${ }^{2}$ Az autoritás előtérbe helyezése vagy a megnyilatkozóról más személyre történő áthelyezése a magyarban nem történhet meg az igealakon, mivel azon a folyamat elsődleges figurája jelölődik. A müvelet azonban a szerint személyragos alakjaival (pl. szerintem, szerinted) a magyarban is begyakorlottan elvégezhető. A Szerinted [tényállás]? típusú kérdések megfelelője a kogi nyelvben az igén történő autoritásjelölés volna (amelyet begyakorlottan alkalmaznak egyszerủ kérdésekben is, amelyek esetében a válasz megadása a partner hatáskörébe tartozik; 1. BERGQVIST 2016; EVANS - BERGQVIST - SAN ROQUE 2018).

Az autoritás mellett további lényeges szempont az, hogy a diskurzus résztvevői közül ki vonódik be az episztemikus státusz mérlegelésébe. A bevonódás ('engagement') terminust grammatikalizálódott jelölőkre alkalmazza a szakirodalom

${ }^{2}$ Észak-kaliforniai indián nyelvekben (chimariko, yana, yurok, karuk) a személyhierarchia alapján meghatározott, kulturálisan kialakított prioritás dönt a személyjelölésröl, és ehhez képest másodlagos az, hogy az adott szereplő ágens-e vagy páciens az adott jelenetben (vö. MITHUN 2012). Bár MiTHUN nem alkalmazza leírásában az autoritás kategóriáját, kimutatja, hogy a szociokulturális tényezők, a társas viselkedés mintázatai egy olyan, a grammatika szempontjából központi jelenséget is a hatásuk alá vonnak, mint az ige argumentumszerkezetének a jelölése. 
(EVANS - BERGQVIST - SAN ROQUE 2018), ${ }^{3}$ a magyarban ilyen rendszert nem találunk. Ugyanakkor a talán típusú episztemikus-inferenciális módosítószók szubjektivizáltan, alaki jelöltség nélkül is a megnyilatkozóhoz kötik a mentális elérést, jelentésüknek nem része, hogy más résztvevő is hozzáférne a következtetés alapját adó jelekhez, vagy az információ nem specifikált forrásához, vagy magához a mentális folyamathoz. (A szubjektivizáció meghatározásához funkcionális kognitív keretben 1. TOLCSVAI NAGY 2017b: 306-309.)

A megosztott elérés ('shared access', vö. JAAKOLA 2018: 123-124) a bevonódás szempontjából szimmetrikus (vö. EVANS - BERGQVIST - SAN ROQUE 2018: 142). A magyarban a -hAtÓAn, -hAtÓlAg komponenst tartalmazó módosítószók (pl. láthatóan, láthatólag; vélhetöleg) a megnyilatkozón keresztüli elérés mellett a megosztott (vagy legalábbis megosztható) státusszal is asszociálódnak.

(3) A törvénytervezetben javasolt négyéves takarékossági ciklus végén rendelkezésre álló, három alapon képződő összeg [...] azonban - láthatóan - új lakás építésére nem elegendő. (MNSZ.)

(4) A [Földrajzi név] déli részén [...] elfogott turisták francia tagja, [Név] láthatólag már beletörődött sorsába. (MNSZ.)

A (3) példa esetében az összeg alapján a beszélőtársak számára is elérhető értékelést ('nem elegendő') fogalmaz meg a megnyilatkozó. Ugyanakkor a beszélőtársak szempontjából nyitott az, hogy egyetértenek-e ezzel a kiértékeléssel. A (4) példában videofelvétel (látható jelek) alapján potenciálisan megfigyelhetőként konstruálja meg a jelenetet a megnyilatkozó, a kiértékelési-következtetési folyamatot (a túsz mentális állapotára vonatkozó következtetést) azonban ez esetben is ő végzi el.

A megosztott elérésre a szakirodalom gyakran a szükebb értelemben vett interszubjektivitás terminust alkalmazza (1. pl. NuYTS 2000: 306; VeRHAGEN 2005). A jelen dolgozat ezt nem követi, mivel az interszubjektivitást a nyelvi szimbolizáció feltételének tartja (1. TÁTRAI 2017: 909-911), és ezért érdemes tőle megkülönböztetni az információhoz való hozzáférés jellegét, amely (mint láttuk) lehet egyéni és megosztott.

Az információhoz való hozzáférés jellege és az episztemikus státusz kiértékelésébe való bevonódás azért is különösen fontos az episztemikus-inferenciális modalitás esetében, mivel rávilágít e szemantikai kategóriának és a hozzá kapcsolódó múveleteknek a társas kognícióba való beágyazottságára. (Ezt a szempontot érvényesíti PÉTERI 2019 is a Common Ground elméletét alkalmazva az episztemikus kifejezések diskurzusfunkciójának a modellálásra.) A fenti szempontok a sokszor összetett perspektívának árnyalt leírását teszik lehetővé.

(5) Nem akartam a dolgok elejébe menni, hiszen komoly vizsgálat indult mind Magyarországon, mind a bizottság berkein belül e témakörben. Azt azonban

${ }^{3}$ Engagement refers to a grammatical system for encoding the relative accessibility of an entity or state of affairs to the speaker and addressee" (EVANS - BERGQVIST - SAN ROQUE 2018: 142). 
mindenképpen megemlítettem, hogy meglehetősen tisztázatlan körülmények között készült filmről van szó, ahol állitólag egy magyarországi libatartó telepet mutattak be és ez a film kb. nyár magasságában készülhetett. (MNSZ.)

Az állitólag módosítószó az (5) példában a következőket jelöli (a felismerhető komponensszerkezetek és a lexikalizálódott jelentés révén, szubjektivizáltan):

a) a megnyilatkozónak értesülésből, pontosan nem azonosított forrásból származó információja van;

b) nem jellemző rá a közvetlen hozzáférés;

c) nem jellemző rá a bevonódás;

d) ezért nem részesedik az információért való felelősségben, sőt annak megbízhatatlanságát implikálja;

e) a megnyilatkozóé a felelősség az információ forrásával és megbízhatóságával kapcsolatos attitüdjének a kifejezéséért.

Az alábbi (6) - az (5)-höz hasonlóan beszélt nyelvi - adat azonban azt mutatja, hogy még az állítólagosként megkonstruált értesülés („hír”, ,szóbeszéd”) is alapot adhat a közeljövő tervezéséhez és a bizakodáshoz.

(6) Sokat nem tudunk csinálni, reménykedik bízunk reménykedünk, és tesszük a dolgunkat, tegnap meg volt az aratás, mert a paraszt az vasárnap is dolgozik, azt strandja járás helyett. Abban bízunk, hogy állitólag kedden Brüsszel alíarja és szerdán már erről fogunk egy előadást is hallgatni. [Sic!] (MNSZ.)

A több perspektíva müködtetésének egy példáját a (7)-ben figyelhetjük meg.

(7) De komolyan: Schumacher valóban a legnagyobb ellenfelem, és sokak számára talán úgy tünt, hogy a kiválásával megnyílt az egyenes út számomra a második világbajnoki címhez. Ám már akkor figyelmeztettem mindenkit: [...] (MNSZ.)

A megnyilatkozó azzal a retorikai fogással él, hogy hipotézist fogalmaz meg mások vélelmeivel kapcsolatban (objektivizáltan, a mentális ágens explikálásával), majd cáfolja ezt a (lehetséges) vélelmet. Egyértelmü, hogy a talán úgy tünik kontextualizáló tagmondaton keresztül elért célszerkezet valószínüsítését (a 'lehetséges' episztemikus státuszát) a megnyilatkozó nem osztja, míg feltételezése szerint mások igen. Ugyanakkor a befogadók episztemikus viszonyának a megkonstruálását a megnyilatkozó végzi el, az övé a vélekedés valószínűsítéséhez tartozó felelősség.

Tehát az episztemikus-inferenciális modalitás jelölőinek előfordulásai igen összetett konstruálási mód részeként dolgozódnak fel. Funkcionális leírásuk a diskurzus mentális világának modelljében lehet sikeres.

3. A modális erö(sség). Az episztemikus-inferenciális módosítószó jelentésének egyik dimenziója a modális erösség ('modal force'). Az erősség többfokozatú skála, az egyes fokozatok viszonylagosak, illetve viszonyítottak. A mentalista, 
logikai-formális szemantikai munkák általában abszolút értékkel adják meg az erősséget. Például KRATZER csökkenő erősségi sorrendben a következő fokozatokat különíti el (KRATZER 1991: 644-645):

a) szükségszerüség (nem lehetséges nem p), pl. feltétlenül, nyilvánvalóan, vitathatatlanul;

b) gyenge szükségszerúség (valószínübb p, mint nem p), pl. alighanem, bizonyára, valószínüleg;

c) lehetségesség (nem szükségszerü nem p), pl. esetleg;

d) „közepes valószínűség” (legalább annyira lehetséges p, mint nem p), pl. feltehetöleg, talán, vélhetöen/vélhetöleg;

e) csekély valószínűség (nem p gyenge szükségszerüség), pl. aligha.

Az ALBERTI GÁBOR által megalkotott ReALIS elméletben és az ebben végzett elemzésekben a vélekedéshez ('believe') kapcsolt intenzitásérték is hasonló elven müködik: „,intenzitásértéket (I elemei: pl. MAX: maximális, gr: nagy; I a [0, 1] számintervallumként is felfogható, ahol a MAX az 1 végponttal azonosítható)" (1. SZETELI-GOCSÁL-ALBERTI 2019: 49).

A formális megközelítések - amennyiben megállapítanak modális erősséget a lexikális kifejezéshez egy meghatározott értéket rendelnek, amely nincs kitéve „esetleges” kontextuális hatásoknak, vagy ha van, azt a modell nem kezeli. Ez az eljárás érthető, hiszen az aktuális jelentés alapján az erősség megítélése igen nagy tartományokban is mozoghat. Az alábbi példák azt mutatják be, hogy a ko- és kontextustól függően a talán által kifejezett modális erősség megítélése nagyon eltérő lehet.

(8) [vizsgatárgy választásáról szóló visszaemlékezésben] Aztán inkább azt gondoltam, hogy legyen biosz. Talán többet tudok róla mondani. (BNYGY.)

(9) Persze elég... nem szemtanútól származik, de föltételezhetjük esetleg, hogy talán a szemtanúktól származó hagyományt őrzi meg. (BNYGY.)

(10) [...] nem tudom, hogy lehetne ezt megoldani, talán határozott fellépéssel, és talán talán inkább az a kulcs, amit te mondtál, hogy partnerként kezelni öket [...] (BNYGY.)

(11) [Tornából hányasa van?] Hát kettes, biztos. Hármast megadja neki talán. (BNYGY.)

Ha ennyire változatos a megvalósulások képe, akkor miért érdemes foglalkozni a modális erősség meghatározásával? A válasz összetett. Egyrészt azért, mert a beszélök (nem feltétlenül tudatosan) feldolgozzák a jelentésnek ezt a dimenzióját, másrészt azért, mert a megvalósulások változatossága természetes jelenség, és semmiképp sem akadálya a tudományos leírásnak, a rendszerszerü összefüggések feltárásának. A jelenség értelmező leírásának a lehetősége természetesen nyelvelméletfüggő módon tárul fel. A továbbiakban ezt a két szempontot vizsgáljuk meg kissé részletesebben. 
Egy kérdőíves vizsgálat (KUGLER 2003: 50) megerősítette, hogy az episztemikus-inferenciális módosítószók a lehetségesség több fokozatán értékelik az információt. Az eredmények azonban azt is mutatták, hogy az adatközlők számára problémát okoz az, hogy értéket kapcsoljanak izolált (kontextus nélkül megadott) kifejezésekhez. Egyhangú megítélés a modális erősségre vonatkozóan csak akkor alakult ki az említett vizsgálatban, ha a módosítószó a modális erősség legnagyobb (pl. kétségbevonhatatlanul, vitathatatlanul) vagy legkisebb fokát jelölte (aligha). Nem elhanyagolható szempont az sem, hogy a vélekedés melletti beszélői elkötelezettség is a szélső értékekkel asszociálódik. Az elkötelezettség pedig azzal függ össze, hogy a pozitív és a negatív pólus szaliensebb, így azonosítása is könnyebb feladat, mint a közrefogott tartományé. Általánosságban megfogalmazható, hogy a lehetségesség közbülső fokait jelölö módosítószók modális erősségének megállapítása nehezebb feladat az adatközlők számára, mint a szélső értékek azonosítása. A sematikus kontextus a „közbülső” kifejezések esetében kevesebb támpontot ad a modális erősség megállapításához. ${ }^{4}$ A modális erősség a meglátásom szerint még típusjelentésében sem logikai úton meghatározható érték, hanem nagymértékben függ a használat tipikus kontextusától, illetve a kontextusok változatosságától. A kontextus előhívása attól is függ, hol tart a kifejezés a grammatikalizáció folyamatában, mennyire azonosítható a kifejezés felismerhető komponense alapján valamilyen mentális művelet (vö.feltehetőleg 'feltevés, feltételezés'; valószinüleg '[mindennapi] valószínüsítés').

A fenti kérdőíves vizsgálat megfigyelése egybevág CORNILLIE azon megállapításával, hogy ,a két szélső érték (a tényállás teljesen bizonyosan igaz és a tényállás teljesen bizonyosan nem igaz) között - a valószínúségtől a lehetségességig - kontinuum van"5 (CORNILLIE 2009: 46).

A modális erőt skálaként meghatározó megközelítések is fenntarthatják a szubjektív-objektív dichotómiát. PÉTERI ATTILA (2015) összevető módon vizsgálta a valószinüleg és a talán kifejezést. A valószinüleg közepes erejét és „köztességét” azzal magyarázza, hogy a ,jelentésében egyfajta »objektív« komponenst hordoz ('ha nem is vagyok benne teljesen bizonyos, mégis megalapozottan állítom, hogy $p^{\prime}$ )" (PÉTERI 2015: 15). Ez a jelentéskomponens szolgál PÉTERInél magyarázatul arra, miért nem cserélhető fel a valószínüleg a talán (és a biztosan) kifejezéssel minden környezetben, és ez az, ami egyben el is különíti ,a tisztán szubjektív-episztémikus”, azaz „pusztán a beszélő episztémikus bizonyosságának, illetve bizonytalanságának fokát” kifejező módosítószóktól (PÉTERI 2015: 10).

${ }^{4}$ Korpuszalapú tipológiai célú kutatások ugyanakkor megerősítik, hogy a valószínüleg, talán típusú, gyenge elkötelezettséget, a modális erősség alacsony értékét képvelő módosítószók a leggyakoribbak, és ezek a kategóriát legjobban képviselő, tipikus módosítószók (1. HORVÁTH 2013: 254-256, 306).

${ }^{5}$ [In betweeen the two extremes (from absolute certainty that a state of affairs is real to absolute certainty that it is not real)], there is a continuum including probability to possibility" (CORNILLIE 2009: 46). A megfogalmazásból az is látható, hogy a hasonló belátás ellenére ez a leírás a jelen dolgozatétól különböző keretben készült. 
Az „objektív” komponens a szerző szerint összefügghet a valószínüség számításon alapuló tudományos kategóriájával. A 2. pontban bemutatott funkcionalista megközelítésben a valószínüleg ilyen megkülönböztetése például a vélhetöleg kifejezéstől nem volna értelmezhető. A 4. pontban adatközlői értékelés alapján vizsgáljuk, milyen bizonyossági fokot fejez ki a valószinüleg és a vélhetöleg kifejezés a számítást előhívó, illetve azt fel nem idéző kontextusban. Arra PÉTERI (2019) is rámutat, hogy bár a kifejezés rendelkezik valamilyen potenciállal a modális erő szempontjából, a modális erősség a diskurzus folyamatában konstruálódik meg, és a felek közös világismeretével függ össze.

A modális erősség megítéléséhez az episztemikus-inferenciális modell minden eleme (1. KUGLER 2015: 55-56), illetve az elemek megalkotott viszonya is hozzájárul egy adott megnyilatkozás esetében. A modell egyik tényezője a modális jelölőhöz kapcsolódó konvencionálódott tudás. A funkcionális kognitív nyelvészet kidolgozott módszertannal rendelkezik ahhoz, hogy a modalitás szemantikai tartományában az erődinamikai modellálást elvégezze. ${ }^{6}$ A vizsgált módosítószók finomhangolják a modellt azáltal, hogy az erő mértékét is kifejezésre juttatják. A jelölőhöz kapcsolódó modális erő séma-megvalósulás viszonyban értelmezhető (TOLCSVAI NAGY 2017a: 33-35). A séma a megvalósulásokból absztrahálódik. Az absztrahálódás a módosítószó esetében a tipikus kontextus sematizációját is jelenti. A séma nem determinálja a megvalósulást, hanem kontextusérzékeny mintaként szolgál az aktuális előhíváshoz. A jelen dolgozat a sémára irányul, ahhoz kíván módszert javasolni, hogyan tárható fel a séma szintü modális erősség. A modális erősség meghatározása ebben a felfogásban a sémák egymáshoz viszonyított erősségének skálaszerü ábrázolását jelenti.

\section{Egy újabb kérdőíves vizsgálat}

4.1. A kérdőív bemutatása. Az új kérdőíves vizsgálat (KUGLER-POMÁzI $2019)^{7}$ olyan módszertannal készült, hogy empirikus adatokat tudjon szerezni a talán, a valószinüleg és a vélhetőleg módosítószó által kifejezett modális erősségről. Az önkitöltéses kérdőívet úgy szerkesztettük meg, hogy ugyanabban a mondatkörnyezetben tudjuk vizsgálni a célkifejezéseket, ezért két változatot készítettünk (1. a tesztmondatokat az 1. táblázatban; a jelen dolgozatban nem tárgyalt, de a vizsgálatban szereplő további kifejezéseket nem közöljük.). A kitöltők feladata az volt, hogy 1-5 Likert-skálán értékeljék a mondatot aszerint, hogy mennyire tartják biztosnak a megnyilatkozót a vélekedésében. Az 1 érték jelölte azt, hogy 'egyáltalán nem', az 5 azt, hogy 'teljes mértékben'.

${ }^{6}$ Lásd ehhez PELYVÁs PÉTER munkáit (a magyar nyelvű tanulmányok közül példaként PELYVÁs 2013-at kiemelve), amelyekben a szerző többféle modális kategória esetében is sikeresen öszszehangolja a langackeri kognitív nyelvtant és a TALMY-féle erődinamikai modellt (illetve annak SWEETSER által a modalitásra kiterjesztett változatát).

${ }^{7}$ A kérdöívet a Kérdöivem alkalmazással készítettük el (1. http://www.kerdoivem.hu). 


\section{1. táblázat}

Az online kérdőív két változatának értékeltetett szerkezetei

\begin{tabular}{|l|l|}
\hline \multicolumn{1}{|c|}{ 1. változat } & \multicolumn{1}{c|}{ 2. változat } \\
\hline Talán megkérdeznek minket is. & Talán megkérdeznek minket is. \\
\hline A számításba valószínüleg hiba csúszott. & A számításba vélhetöleg hiba csúszott. \\
\hline $\begin{array}{l}\text { A kutya vélhetöleg féltékenységböl támadt } \\
\text { a gyerekre. }\end{array}$ & $\begin{array}{l}\text { A kutya valószinüleg féltékenységböl tá- } \\
\text { madt a gyerekre. }\end{array}$ \\
\hline
\end{tabular}

A táblázatból látható, hogy a talán ugyanabban a mondatban fordult elö mindkét kérdőívben, így fény derülhet arra, hogy 1 . a két adatközlöi csoport döntései mennyire hasonlóak; 2. a másik két kifejezés átlagához hogyan viszonyul az átlagos erőssége. A valószinüleg és a vélhetöleg kifejezést két különbözö mondatban is megítéltettük. Ebből kiderülhet, hogy 1. az eltérö kotextus gyakorol-e az átlagértékben kifejeződő hatást a modális erősség meghatározására, és hogy 2. az azonos kotextusban milyen a modális erő mértéke.

A kérdőívet 66 adatközlő (33-33) töltötte ki, mindannyian magyar alapszakos vagy magyartanári képzésben részt vevő ELTE BTK-hallgatók voltak. ${ }^{8} \mathrm{~A}$ kitöltők átlagéletkora az 1. kérdőív esetében 22,5 év, a 2. kérdőív esetében 20,9 év volt. Az életkoron kívül más személyes adatot nem rögzítettünk. A két kérdőívet célzottan küldtük ki, így senki sem tölthette ki mindkét változatot, csak az egyikhez fért hozzá. A kitöltés 2019. február 21-e és március 17-e között zajlott.

4.2. Eredmények és következtetések. A 2. táblázat az adatközlök által az adott mondat alatti ötös Likert-skálán bejelölt értékeknek az átlagát közli. Az 1. és a 2. a kérdőívre, illetve kitöltői csoportra utal.

\section{2. táblázat}

A Likert-skálán bejelölt értékek átlaga

\begin{tabular}{|c|c|c|c|}
\hline \multirow{2}{*}{ Tesztmondat } & \multicolumn{2}{|c|}{ Átlag } & \multirow{2}{*}{ Módosítószó } \\
\hline & 1. & 2. & \\
\hline A számításba valószínüleg hiba csúszott. & 3,33 & - & valószínüleg \\
\hline A számításba vélhetöleg hiba csúszott. & - & 3,24 & vélhetöleg \\
\hline A kutya valószínüleg féltékenységből támadt a gyerekre. & - & 2,82 & valószínüleg \\
\hline A kutya vélhetőleg féltékenységből támadt a gyerekre. & 2,55 & - & vélhetöleg \\
\hline Talán megkérdeznek minket is. & 2,39 & 2,06 & talán \\
\hline
\end{tabular}

Az adatközlöi értékelés hasonló volt a két csoportban (az eltérés a talán átlaga esetében 0,33), az átlag a 2. csoportban volt kissé alacsonyabb. Ezzel látszólag összefügghet, hogy a valószínüleg is a 2. csoportban kapott alacsonyabb értéket, de a különbség valamivel nagyobb (az eltérés 0,51). Mivel azonban a vélhetöleg

${ }^{8}$ A kitöltők szervezéséhez nyújtott segítséget köszönöm LENGYEL KLÁRA egyetemi docensnek. A részvételt ezúton is köszönöm a hallgatóknak. 
nagyobb átlagot ért el a 2. csoportban, az átlagok különbsége nem magyarázható az adatközlői értékelés csoportszintü különbségével. Az értékek alapján a kotextusnak nagyobb hatása van a megnyilatkozói bizonyosság (közvetve a modális erő) megítélésére, mint a csoportszinten kumulálódó egyéni adatközlői különbségeknek. A számítás esetében a hiba megállapítása nagyobb bizonyossággal történhet, mint a kutya támadása esetén a viselkedés mozgatórugójának az azonosítása. A kotextus hatása mellett azonban az is megfigyelhető, hogy a két nyelvi kifejezés (valószinüleg, vélhetöleg) nem teljesen azonos mértékü bizonyosságot jelöl, bár mindkettő a közepes tartományba esik. Azonos mondatkörnyezetben a valószínüleg nagyobb értékeket kapott, mint a vélhetöleg. Tehát a közepes erösség tartományban a valószínüleg kifejezéshez sémaszerüen valamivel nagyobb fokú beszélöi bizonyosság kapcsolódik, mint a vélhetöleg-hez. A talán esetében nem vizsgáltuk a kotextus hatását. Az értékelés alapján azonban úgy tünik, hogy a három kifejezés közül a talán asszociálódik a legkisebb modális erővel, és a skálán a közepesnél alacsonyabb, kismértékủ bizonyosságot jelöl.

Ha a kapott értékek megoszlását is megvizsgáljuk, akkor az adatok megerősítik a megítélés problematikusságáról a 3. pontban festett képet. Az 1. ábra az azonos mondatkörnyezet alapján állítja párba a kifejezéseket.

\section{1. ábra}

A valószínüleg és a vélhetőleg értékeinek megoszlása
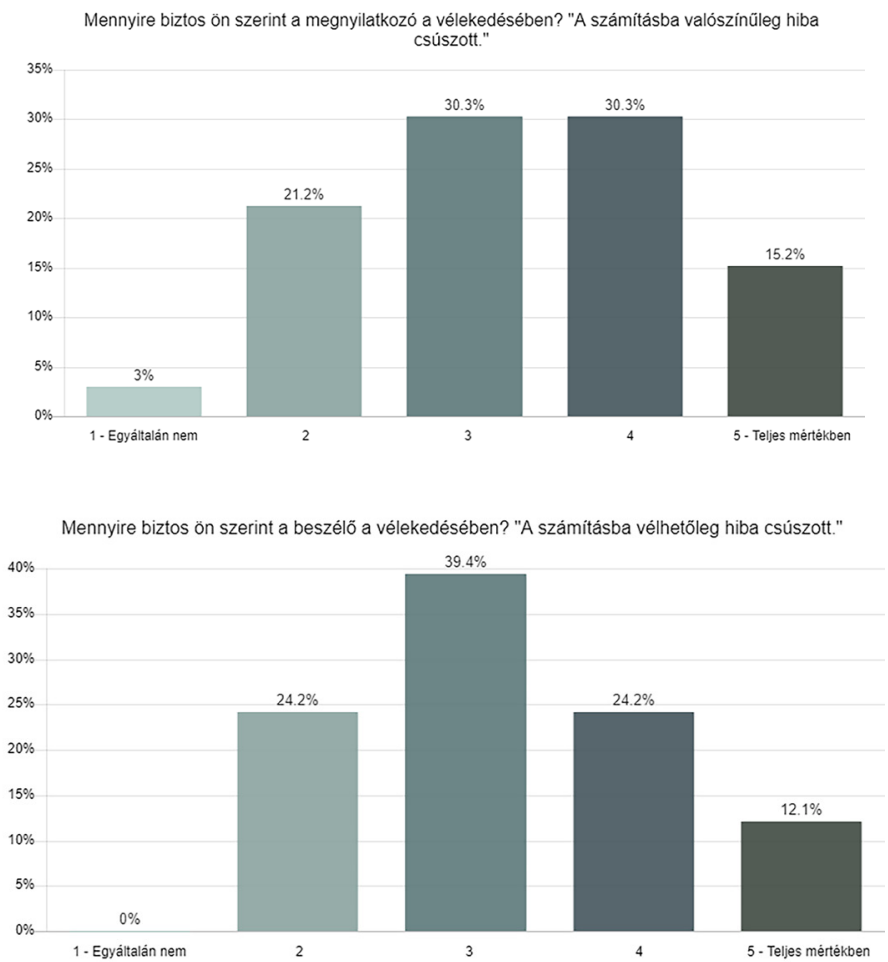

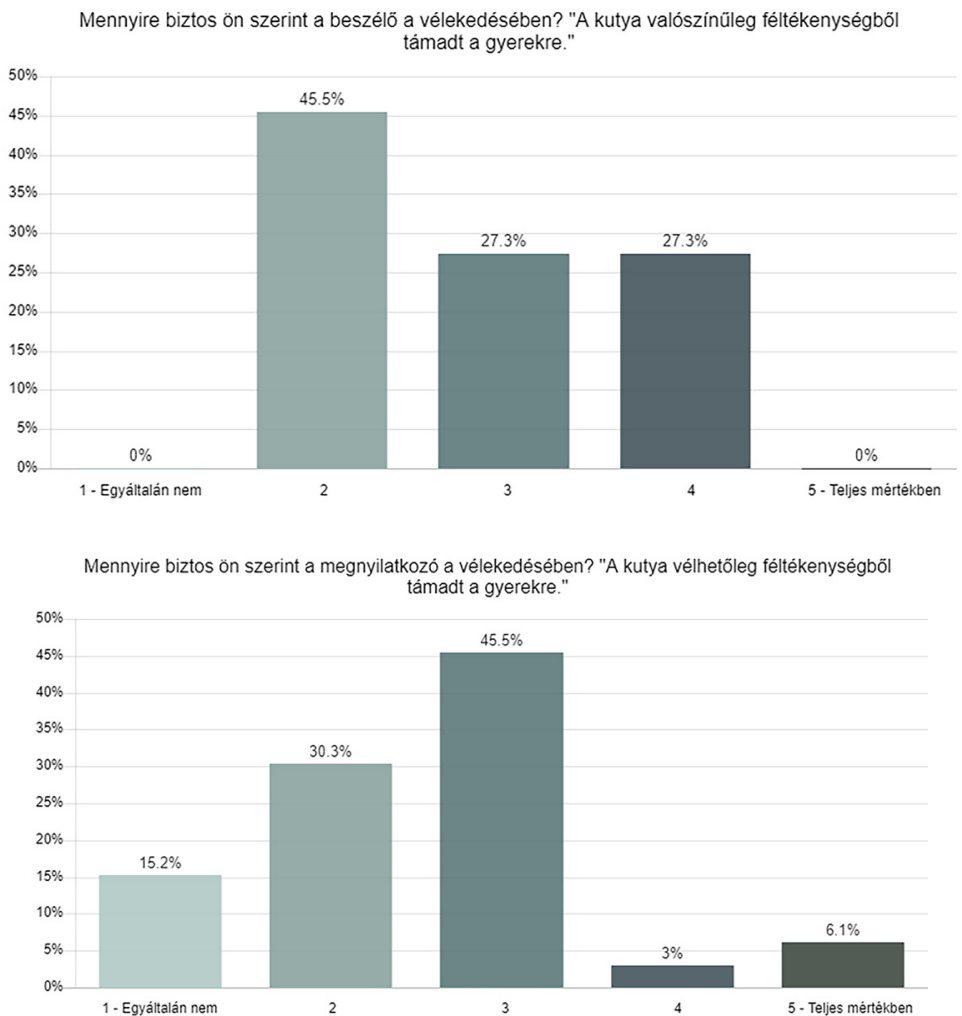

Mindkét kifejezés esetében a 2-4 közötti érték a jellemző. A talán esetében (1. a 2. ábrát) a kiemelkedő érték a 2 ('alacsony fokú, kicsiny mértékü bizonyosság'), az 1-3 értékelés a jellemző. A vélhetöleg és a talán esetében egy árnyalattal jobban megoszlik az értékelés, mint a valószínüleg-nél.

\section{2. ábra}

A talán értékeinek megoszlása

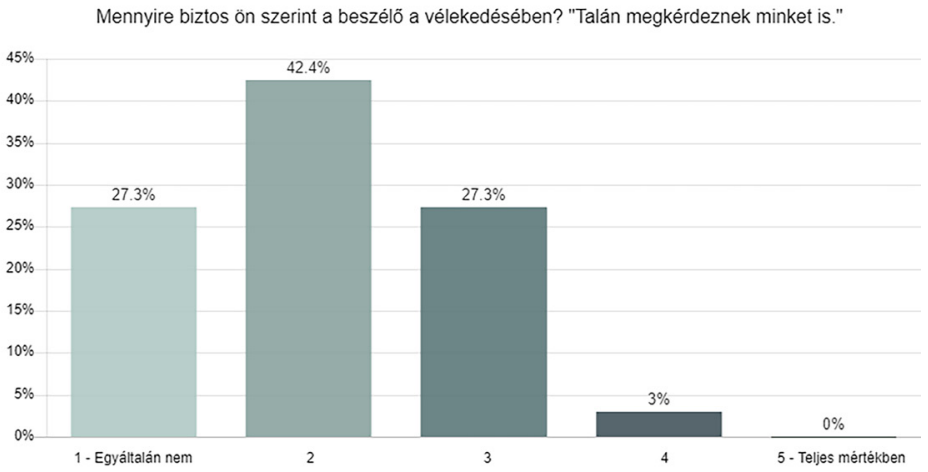




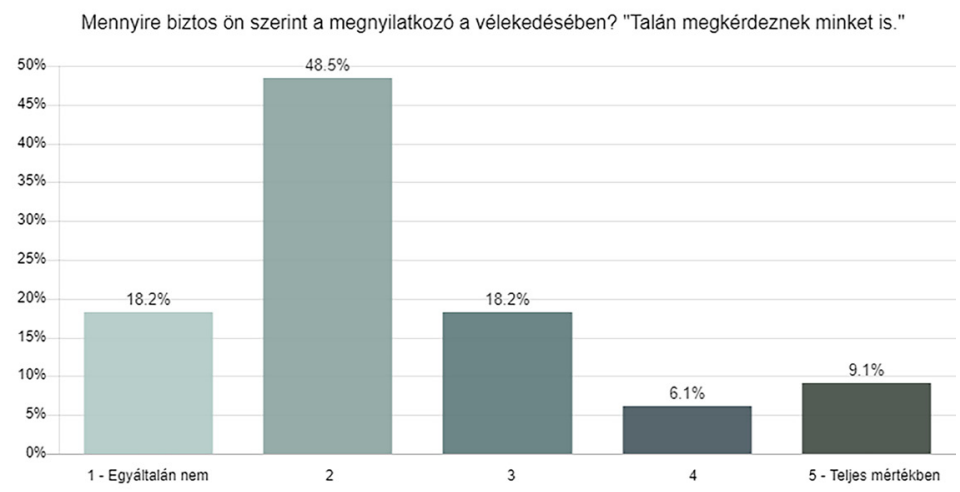

Bár a bizonyosság legnagyobb fokának választása a valószinüleg esetében volt a legnagyobb arányú $(15,2 \%)$, ez nem múlta felül számottevően a vélhetöleg 12\%-át (azonos kotextusban). Az 5-ös érték választása még a talán kifejezés esetében is elöfordult ( $9,1 \%$-ban).

Az eredmények megerősítik azt, hogy az episztemikus státusz értelmezése, és ezért a valószínűsítéshez kapcsolódó modális erő megítélése is erősen ko(n)textusfüggő, beágyazódik a diskurzus mentális világába, a résztvevők világértelmezésébe. Ugyanakkor a tipikus kontextus alapján a modális erő jellemző tartománya sematizálódik, és ez a kérdőív teszthelyzetében is müködésbe lép. Ezzel magyarázható az, hogy az adatközlők jellemző sávokban helyezték el a beszélői bizonyosság alapján a kifejezéseket. Hasznos lenne azonban azt is megvizsgálni, hogy a kifejezések milyen sematikus kontextust hívnak elő. Erre alkalmas volna egy olyan előhívásos feladat, amelyben az adatközlőknek megnyilatkozást kellene alkotniuk az adott (izolált) kifejezéssel, majd ezt követően el kellene végezniük a kontextus elaborálást is. Az így előhívott adatok modális erő szerinti értékelését azután az itt bemutatotthoz hasonló értékelésnek lehetne alávetni.

5. Összefoglalás. A modális erősséget azért szükséges vizsgálni, mert az sematizáltan, egy skála viszonyított értékeinek tartományaként része a módosítószó jelentésének, és ezért a nyelvi interakcióban a beszélők (nem feltétlenül tudatosan) fel is dolgozzák a jelentésnek ezt a dimenzióját. Ez a sémaszintü jelentés nem logikai úton meghatározható érték, hanem nagymértékben függ a használat tipikus kontextusától, illetve a kontextusok változatosságától. A megvalósulások esetében a tipikus (séma szintü) modális erősség kontextusérzékeny mintaként szolgál az aktuális előfordulás értelmezéséhez. A modális erő megkonstruálásában szerephez jut a következtetést végző mentális szubjektum (megosztott hozzáférés esetén szubjektumok) és a következtetés alapjának, valamint a jelenetnek a megértett viszonya. A jelen dolgozat csak megemlítette, de nem vizsgálta az episztemikus-inferenciális modalitás modelljének egyéb elemeit (1. KUGLER 2015), amelyek segítségével megközelíthető annak nyelvi reprezentációja, ahogy a diskurzus résztvevői egymás mentális müködését befolyásolják és összehangolják a természetes episztemológia jelenségeinek körében. 
A kifejezések megválasztásánál a dolgozat figyelembe vette, hogy a talán, a valószínüleg és a vélhetöleg eltérö komponensszerkezettel rendelkezik. A mentális folyamat jellege csak a valószinüleg és a vélhetöleg esetében van komponenssel kidolgozva, a hozzáférés megosztott jellege pedig leginkább a vélhetôleg módosítószónál hívható elő ('a mentális folyamat potenciálisan más mentális szubjektumokra is kiterjesztő' jelentés révén).

A kérdőíves vizsgálat megerösítette, hogy a valószinüleg és a vélhetöleg közepes erősségű valószínüsítést jelöl, mivel eltérő kontextusokban is közepes mértékü beszélői bizonyosság asszociálódott velük. A talán esetében ilyen következtetésre az adatok alapján nem nyílik lehetőség, de az értékelés így is támogatja a korábbi szakirodalmi forrásokat, amelyek alacsony valószínüségi fok jelölését feltételezték vagy adatolták. Ezzel együtt azonban az is ismételt tapasztalatként rögzíthető, hogy a kifejezések modális erősségének a megítélése az értékek között igencsak megoszlik, a teljes bizonyosság és a teljes bizonytalanság, továbbá a köztük lévő átmenetek egyaránt előfordulnak. A „teljes spektrumú lefedésre” mindhárom kifejezés esetében volt példa. A dolgozat javaslatot fogalmazott meg olyan vizsgálatra, amely kifejezetten a sematikus kontextus és a tipikus modális erősség előhívását célozza.

Kulcsszók: episztemikus-inferenciális modalitás, modális erő, séma-megvalósulás viszony.

\section{Hivatkozott irodalom}

BERGQVIST, HENRIK 2016. Complex epistemic perspective in Kogi (Arwako). International Journal of American Linguistics 82: 1-34. https://doi.org/10.1086/684422

CORNILLIE, BERT 2009. Evidentiality and epistemic modality. On the close relationship between two different categories. Functions of Language 16: 44-62. https://doi. org/10.1075/fol.16.1.04cor

EVANS, Nicholas - BERGQVist, HeNRIK - SAN Roque, Lila 2018. The grammar of engagement II: typology and diachrony. Language and Cognition 10: 141-170. https:// doi.org/10.1017/langcog.2017.22

HoRVÁTH, KATALIN 2013. Epistemische Modalität im Deutschen und Ungarischen. Budapester Beiträge zur Germanistik 66. ELTE, Budapest.

JAAKOLA, MINNA 2018. Finnish evidential adverbs in argumentative texts. In: Foolen, AD - DE HOOP, HELEN - MULDER, GIJS eds., Evidence for evidentiality. John Benjamins, Amsterdam-Philadelphia. 121-141. https://doi.org/10.1075/hcp.61.06jaa

KratZer, ANGELIKA 1991. Modality. In: VON STECHOW, ARNIM - WUNDERLICH, DieTER eds., Semantik/Semantics. Walter de Gruyter, Berlin - New York. 639-50.

KUGLER NÓRA 2003. A módosítószók funkciói. Nyelvtudományi Értekezések 152. Akadémiai Kiadó, Budapest.

KUGLER NÓRA 2015. Megfigyelés és következtetés a nyelvi tevékenységben. Tinta Könyvkiadó, Budapest.

KUGLER NÓRA - POMÁZI BENCE 2019. A látással összefüggő, kiértékelést kifejező episztemikus predikáció alternatív megkonstruálási módjai. In: LACZKÓ KRISZTINA - TÁTRAI 
SzILÁRD szerk., Kontextualizáció és metapragmatikai tudatosság. DiAGram Könyvek 1. ELTE Eötvös József Collegium, Budapest. 71-94.

Mithun, MARIANNE 2012. Core argument patterns and deep genetic relations. Hierarchical systems in Northern California. In: SUIHKONEN, PIRKKO - COMRIE, BERNARD Solovyev, VAlEy eds., Argument structure and grammatical relations. A crosslinguistic typology. John Benjamins, Amsterdam-Philadelphia. 257-294. https://doi. org/10.1075/slcs.126.12mit

NUYTS, JAN 2000. Epistemic modality, language, and conceptualization. John Benjamins, Amsterdam-Philadelphia.

OraVecz, CSABA - VÁRAdi, TAMÁS - SASS, BÁlint 2014. The Hungarian Gigaword Corpus. In: LREC 2014 Proceedings. ELRA, Reykjavik. 1719-1723.

PELYVÁs PÉTER 2013. „Nekem most el kell menjek...” A kell és a must segédigék konceptuális és grammatikai struktúrájáról. In: KUGLER NÓRA - LACZKÓ KRISZTINA TÁTRAI SZILÁRD szerk., A megismerés és az értelmezés konstrukciói. Tanulmányok Tolcsvai Nagy Gábor tiszteletére. Tinta Könyvkiadó, Budapest. 186-203.

PÉTERI ATTILA 2015. A valószínüleg mondathatározó szemantikája és szintaxisa kontrasztív kitekintéssel. Magyar Nyelv 111:9-20. https://doi.org/10.18349/magyarnyelv.2015.1.9

PÉTERI, ATTILA 2019. Epistemik und Common Ground. Quantitative und qualitative Untersuchung epistemischer Ausdrücke im Korpus. Linguistik Online 100/7: 235-258. https://bop.unibe.ch/linguistik-online (2020. 07. 17.)

SZETELI ANNA - GOCSÁL ÁKOS - ALBERTI GÁBOR 2019. Szemafor hát! Jelentés és Nyelvhasználat 6/1: 33-63. https://doi.org/10.14232/JENY.2019.1.2

TÁTrAi SzILÁrD 2017. Pragmatika. In: TolCSVAi NAGY szerk. 2017: 899-1058.

TOlCSVAi NAGY GÁBOR 2017a. Bevezetés. In: TOlCSVAI NAGY szerk. 2017: 23-71.

TOlCSVAi NAGY GÁBOR 2017b. Jelentéstan. In: TolCSVAI NAGY szerk. 2017: 207-499.

TOlCsVAi NAGY GÁBOR szerk. 2017. Nyelvtan. A magyar nyelv kézikönyvtára 4. Osiris Kiadó, Budapest.

Verhagen, ARIE 2005. Constructions of intersubjectivity. Discourse, syntax and cognition. Oxford University Press, Oxford.

\section{Is it worth measuring modal force? If it is, how?}

Based on a questionnaire study on three Hungarian modal adverbs (talán 'perhaps', valószinüleg 'probably', vélhetöleg 'presumably'), the paper argues for the necessity of investigating modal force, and for interpreting it from a functional perspective. Modal force is a context-dependent phenomenon, with broad variation at the level of tokens. Still, at the schema level, it is possible to establish typical schematic contexts and associated characteristic modal forces. The paper offers an empirical methodology for exploring such schemas.

Keywords: epistemic-inferential (epistential) modality, modal force, schematization, type vs. instance.

KUGLER NÓRA

ELTE Eötvös Loránd Tudományegyetem 